\section{Effect of Rootstock on Stem-end Rind Breakdown and Decay of Fresh Citrus}

\author{
Mark A. Ritenour ${ }^{1}$, \\ Huating Dou ${ }^{2}$, \\ Kim D. Bowman ${ }^{3}$, \\ Brian J. Boman ${ }^{1}$, Ed Stover ${ }^{1}$, \\ and William S. Castle ${ }^{4}$
}

AdDitional INDEX wORDs. SERB, storage, 'Valencia' orange, navel orange, 'Oroblanco', 'Ray Ruby' grapefruit

Summary. Rootstock significantly affected the development of stem-end rind breakdown (SERB) on 'Valencia' and navel oranges (Citrus sinensis), but not 'Ray Ruby' grapefruit ( $C$. paradisi) or 'Oroblanco' (C. grandis $x$ C. paradisi), and affected postharvest decay on navel orange, 'Ray Ruby' grapefruit, 'Oroblanco' and one of two seasons (2002) on 'Valencia' orange. In 'Valencia' and navel oranges, fruit from trees grown on Gou Tou (unidentified Citrus hybrid) consistently developed low SERB. 'Valencia' oranges on US-952 [ $C$. paradisi $\times$ C. reticulata) $\times$ Poncirus trifoliata] developed high levels of SERB in both years tested. Relative SERB of fruit from other rootstocks was more variable. Navel oranges, 'Ray Ruby' grapefruit, and 'Oroblanco' fruit from trees on Cleopatra mandarin (C. veticulata) rootstock consistently developed relatively low levels of decay, and in navel this level

This research was supported by the Florida Agricultural Experiment Station, and approved for publication as Journal Series No. R-09635. The use of trade names in this publication does not imply endorsement by the University of Florida Institute of Food and Agricultural Sciences of the products nor criticism of similar ones not mentioned.

${ }^{1}$ University of Florida-IFAS, Indian River Research and Education Center, 2199 S. Rock Rd., Ft. Pierce, FL 34945-3138. To whom reprints should be requested; e-mail address: mritenour@ifas.ufl.edu

${ }^{2}$ Florida Department of Citrus, Citrus Research and Education Center, 700 Experiment Station Road, Lake Alfred, FL 33850-2299.

${ }^{3}$ United States Department of Agriculture, Agricultural Research Service, U.S. Horticultural Research Laboratory, 2001 S. Rock Rd., Fort Pierce, FL 34945

${ }^{4}$ University of Florida-IFAS, Citrus Research and Education Center, 700 Experiment Station Road, Lake Alfred, FL 33850-2299 was significantly lower than observed from trees on all other rootstocks. In three of five trials we observed significant differences between widely used commercial rootstocks in their effects on postharvest SERB and/or decay. Given the expanding importance of sales to distant markets, it is suggested that evaluations of quality retention during storage be included when developing citrus rootstocks and scion varieties for the fresh market.

S tem-end rind breakdown (SERB) is an important physiological peel disorder that causes economic loss to Florida oranges and grapefruit each year (Dou et al., 2001; Grierson, 1986; Hopkins and McCornack, 1960). SERB is characterized by the collapse of rind tissue around the stem end of citrus fruit. The affected area is irregular in shape and becomes dark and sunken. A 2 - to 5-mm (0.08-0.20 inch) ring of unaffected tissue immediately around the stem (button) is a distinctive symptom of SERB; that area contains a thick layer of natural wax on the cuticle and no stomata (Albrigo, 1972). SERB symptoms usually develop within 2 to $7 \mathrm{~d}$ after packing. Thinner-skinned fruit from humid growing environments such as Florida are more prone to SERB than thicker-skinned fruit grown in arid environments (Grierson, 1965). In addition, small or well-colored fruit tend to develop more severe SERB. Fruit with SERB are also more susceptible to infection by decay-causing organisms (McCornack and Grierson, 1965).

Both preharvest and postharvest factors affect SERB development. During postharvest handling, SERB is primarily associated with conditions that cause excessive water loss from the peel, particularly between harvest and waxing (Grierson, 1986; Hopkins and McCornack, 1960; McCornack and Grierson, 1965). Conditions enhancing water loss include delays between harvest and wax application, holding the fruit under low humidity and high temperatures, and excessive air movement around the fruit (Grierson, 1986; Hopkins and McCornack, 1960; McCornack and Grierson, 1965 ). Dou et al. (2001) reported that SERB development was significantly affected by the type of wax (shellac, carnauba, and polyethylene) and to a greater extent by the specific wax formulation used by different manufacturers.
Of the preharvest factors that influence SERB development, tree nutrition has been investigated most thoroughly (Agusti, 1999; Grierson, 1965 ). Researchers have suggested that nutritional imbalances involving high nitrogen and low potassium may predispose fruit to SERB (Agusti, 1999). After many years of research under Florida conditions, Grierson (1965) reported that such relationships fell just short of significance at $P \leq 0.05$. This may suggest that other factors play a greater role in the occurrence of SERB.

Rootstocks affect a wide range of citrus tree and fruit quality characteristics including canopy size, mineral uptake, cold hardiness, juice Brix concentration, titratable acidity, and fruit yield, shape, puffiness, internal granulation, albedo breakdown, and susceptibility to chilling injury (Agusti, 1999; Castle, 1987; D'hallewin et al., 1994; McCollum et al., 2002; Patil, 2001; Treeby et al., 1995; Zekri, 2000). Given the importance that rootstocks play in influencing tree and fruit characteristics, it is reasonable that rootstock may also play an important role in the development of SERB. The authors could find no reports investigating this possible relationship in the literature.

Furthermore, there remains little reported research on the effect of rootstock on susceptibility of fresh citrus fruit to postharvest decay. McDonald and Wutscher (1974) evaluated postharvest decay of 'Redblush' grapefruit from 21 different rootstocks in Texas and report significant effects. However, $80 \%$ of the postharvest decay was caused by green mold (Penicillium digitatum), while in Florida, stem-end rots (especially Diplodia natalensis) are commonly the primary cause of decay. The objective of this research was to investigate how rootstock influences postharvest SERB and decay development in different fresh citrus fruit varieties grown in Florida.

\section{Materials and methods}

Methods COMmon TO ALL EXPERIMENTS. In each experiment, fruit were compared from trees on different rootstocks in plots which were established and maintained as randomized complete block trials, so that the effects observed should be attributed primarily to differences resulting from the rootstocks used. The citrus trees 
received standard commercial care in the field except where noted. Commercially mature (Florida Department of State, 2003) and healthy fruit were harvested randomly from mid-level on healthy trees, evenly spaced around the tree and dispersed within inner and outer canopy fruit. Approximately equal numbers of fruit were harvested from one tree ('Oroblanco'), two trees ('Valencia' oranges and 'Ray Ruby' grapefruit), or three trees (navel oranges) per replicate and combined. Very few blemishes were found on the fruit after harvest so that almost all fruit were used during postharvest evaluations. Harvested fruit replicates were kept separate and, unless otherwise indicated, were transported to the Citrus Research and Education Center (CREC) at Lake Alfred, Fla., where they were washed, coated with a shellac wax (HS 590; FMC Food Tech, Lakeland, Fla.), and stored. No postharvest fungicide was applied to the fruit in any of the experiments and all fruit were stored in 4/5-bu $(28.2 \mathrm{~L})$ corrugated fiberboard citrus cartons. Fruit were stored at designated temperatures at $90 \%$ relative humidity. For all experiments, fruit were inspected for SERB and decay at regular intervals during storage and the experiment terminated after adequate $(\sim 20 \%$ to $50 \%)$ SERB or decay had developed. Decayed fruit were removed at each inspection, but fruit with SERB were not. Presence of any SERB or decay symptoms caused a fruit to be scored in the appropriate category. In all cases, the data collected were cumulative number of fruit showing either SERB or decay and expressed as percentage of the fruit initially placed in each carton.

'VALENCIA' ORANGes. 'Valencia' oranges budded on different rootstocks and planted in 1991 near Lynchberg, Fla. (Wutscher and Bowman, 1999) were harvested on 24 Apr. 2001. About 100 fruit were harvested from each of four replicates. The rootstocks evaluated were: 1) Carrizo citrange (Carrizo; Citrus sinensis x Poncirus trifoliata), 2) Gou Tou (unidentified Citrus hybrid), 3) US-952 [( C. paradisi $\times C$. reticulata) $\times$ P. trifoliata $]$, 4) Sun Chu Sha mandarin (SCS; C. reticulata), 5) US-812 (C. reticulatax P. trifoliata), 6) US-942 (C. reticulata $x$ P. trifoliata), 7) Swingle citrumelo (Swingle; C. paradisi $\times$ P. trifoliata), and 8) Vangasay lemon (Vangasay; $C$. limon).
Cumulative percentages of decayed fruit or fruit with SERB are reported after $41 \mathrm{~d}$ storage at $70{ }^{\circ} \mathrm{F}$ $\left(21.1^{\circ} \mathrm{C}\right)$, or after 50 and $101 \mathrm{~d}$ storage at $38^{\circ} \mathrm{F}\left(3.3^{\circ} \mathrm{C}\right)$. The experiment was repeated in 2002 on fruit harvested 15 May from the same trees and cumulative SERB and decay reported after 35 $\mathrm{d}\left(70{ }^{\circ} \mathrm{F}\right)$ or $98 \mathrm{~d}\left(38^{\circ} \mathrm{F}\right)$ of storage.

NAVEl ORANGes. Navel oranges budded on different rootstocks and planted in 1991 near Ft. Pierce, Fla. were harvested on 12 Nov. 2001. The rootstocks evaluated were, 1) Carrizo, 2) Cleopatra mandarin (Cleopatra; C. reticulata), 3) Gou Tou, 4) SCS, and 5) Swingle. Approximately 120 fruit were harvested randomly from each of four replicates per rootstock. Fruit were held at $50^{\circ} \mathrm{F}\left(10.0^{\circ} \mathrm{C}\right)$ and cumulative SERB and decay reported after $60 \mathrm{~d}$ storage.

'RAY RubY' GRAPEFruit. 'Ray Ruby' grapefruit budded on different rootstocks and planted in 1990 at the Indian River Research and Education Center (IRREC) in Ft. Pierce, Fla. received standard commercial care, except that trees were irrigated throughout the year using well water with $500 \mathrm{ppm}\left(\mathrm{mg} \cdot \mathrm{L}^{-1}\right)$ total dissolved solids [TDS, electrical conductivity $\left.(\mathrm{EC})=0.7 \mathrm{dS} \cdot \mathrm{m}^{-1}\right]$ or water with 3800 ppm TDS $\left(\mathrm{EC}=5.4 \mathrm{dS} \cdot \mathrm{m}^{-1}\right)$. There was no significant effect of the TDS on SERB or decay and no interaction with the rootstock effect (data not shown). The rootstocks evaluated were: 1) Carrizo, 2 ) Cleopatra, 3 ) sour orange $(C$. aurantium), and 4) Swingle. About 60 fruit were harvested for this study on 16 Jan. 2002 randomly from each of three replicates per rootstock. Cumulative SERB and decay are reported after $37 \mathrm{~d}$ at $70{ }^{\circ} \mathrm{F}$, or $98 \mathrm{~d}$ at $50{ }^{\circ} \mathrm{F}$.

'Oroblanco'. 'Oroblanco' is a seedless pummelo $x$ grapefruit hybrid (Soost and Cameron, 1980) that ripens earlier than grapefruit, but is similar in flavor and appearance. 'Oroblanco' trees budded on different rootstocks and planted in 1993 at the IRREC in Ft. Pierce, Fla. (Stover et al., 2004) were harvested for this study on 8 Oct. 2002. The rootstocks evaluated were, 1) Carrizo, 2) Cleopatra, 3) Gou Tou, 4) rough lemon 8166 (C. jambbiri) 5 ) Smooth Flat Seville (SFS; unidentified Citrus hybrid), 6) SCS, 7) Swingle, 8) Volkamer lemon (C. volkameriana), and 9) $\times 639$ (C. reticulata $\times$ P. trifoliata). About 25 fruit were harvested randomly from each of four replicates per rootstock. Fruit were washed and coated with a shellac wax (HS 590; FMC Food Tech) at the IRREC, held at $50^{\circ} \mathrm{F}$, and cumulative SERB and decay reported after $101 \mathrm{~d}$ storage.

Statistical analysis. Percentage data were transformed to arcsine values and analyzed by analysis of variance using SAS (PROC GLM) for PC (SAS Institute, Cary, N.C.). Analyses were based on the initial design of the rootstock trials. When differences were significant $(P<0.05)$, individual treatment means were separated using Duncan's multiple range tests $(P=$ $0.05)$. Means presented are untransformed values.

\section{Results and discussion}

'VALENCIA' ORANGES. SERB is a common postharvest disorder of 'Valencia' oranges in Florida (McCornack and Grierson, 1965). Hopkins and McCornack (1960) reported that $9 \mathrm{~d}$ after harvest at $\sim 76^{\circ} \mathrm{F}\left(24.4^{\circ} \mathrm{C}\right), 29 \%$ to $38 \%$ of 'Valencia' oranges developed SERB if washing and waxing was delayed for $2 \mathrm{~d}$. After 41 or $101 \mathrm{~d}$ storage at 70 or $38{ }^{\circ} \mathrm{F}$, respectively, $21 \%$ to $56 \%$ of the fruit harvested in 2001 developed SERB symptoms (Table 1). Following storage of 4l-50 d, 'Valencia' oranges held at $38^{\circ} \mathrm{F}$ developed $\sim 10$-fold less SERB than fruit stored at $70^{\circ} \mathrm{F}$. Dou et al. (2001) also noted a large reduction in SERB when 'Valencia' fruit were held at lower temperatures [ 40 vs. 70 ${ }^{\circ} \mathrm{F}\left(4.4\right.$ vs. $\left.\left.21.1^{\circ} \mathrm{C}\right)\right]$. Although SERB can begin to develop within 2 to $7 \mathrm{~d}$ after harvest, the percentage of fruit with SERB increased greatly between 50 and $101 \mathrm{~d}$ storage at $38^{\circ} \mathrm{F}$. Continued water loss from the fruit during the additional $5 \mathrm{l} \mathrm{d}$ of storage may have been a factor causing continued SERB development. SERB levels after $4 \mathrm{l} d$ at $70{ }^{\circ} \mathrm{F}$ were comparable to SERB levels observed after $101 \mathrm{~d}$ at $38^{\circ} \mathrm{F}$.

Decay of stored 'Valencia' oranges was also delayed at the lower temperature with less than $3 \%$ decay in fruit stored $50 \mathrm{~d}$ at $38^{\circ} \mathrm{F}$ (data not shown) compared to $11 \%$ to $20 \%$ decay in fruit stored for $4 \mathrm{l} \mathrm{d}$ at $70^{\circ} \mathrm{F}$ (Table $\mathrm{l}$ ). The delay in decay and SERB development on fruit stored at lower temperature is also evident in Table 2. Cumulative SERB development after $38^{\circ} \mathrm{F}$ storage in 2002 was significantly lower than in 2001 on fruit harvested from the same trees. Fruit stored at $70^{\circ} \mathrm{F}$ was not analyzed on an annual basis because of the different storage durations. 
Table 1. Effects of rootstock on the percentage of 'Valencia' oranges developing stem-end rind breakdown (SERB) and decay during storage at 70 or $38^{\circ} \mathrm{F}\left(21.1\right.$ or $\left.3.3{ }^{\circ} \mathrm{C}\right)$, both with $90 \%$ relative humidity (2001).

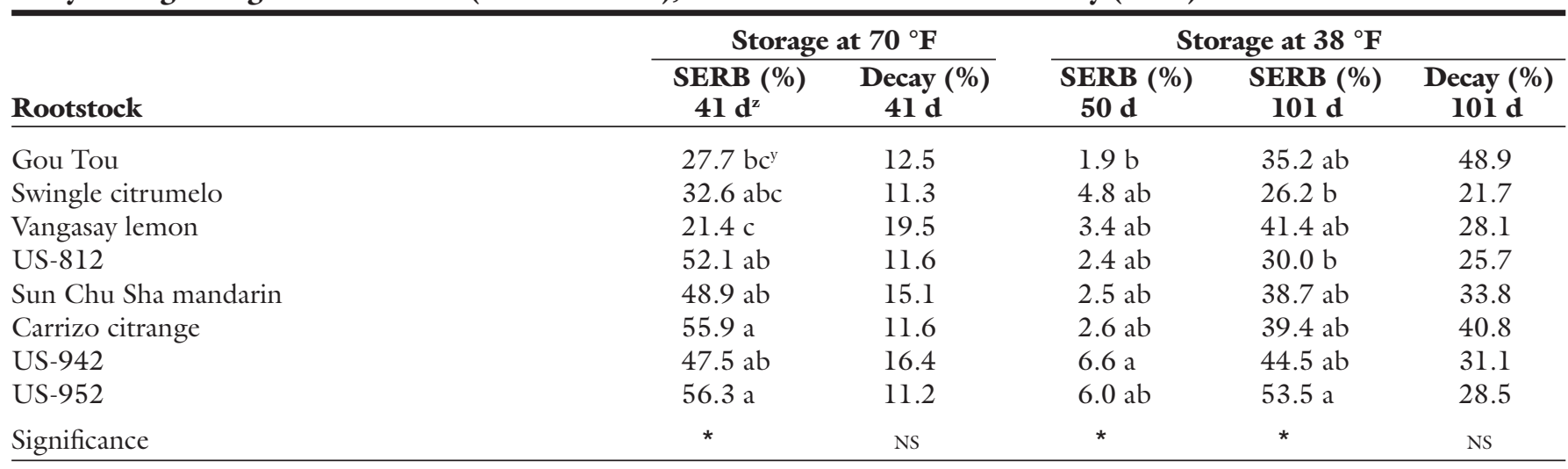

${ }^{2}$ Days after harvest.

Values within each column followed by unlike letters are significantly different by Duncan's multiple range test at $P \leq 0.05$.

ss, *Nonsignificant or significant at $P \leq 0.05$

Thus, other preharvest factors such as changes in temperature, rainfall, etc. can greatly affect the susceptibility of fruit to SERB. Grierson (1965) cited work by Stearns (1942) showing a decline in SERB of 'Valencia' oranges if harvest was delayed during dry weather until after irrigation and suggested that SERB may become more severe after trees are water stressed during the growing season. There was no year and rootstock interaction related to either SERB or decay development in fruit stored at $38^{\circ} \mathrm{F}$.

With 'Valencia' oranges, use of different rootstocks significantly affected both SERB and, to a much lesser degree, decay (Tables 1 and 2). Postharvest decay was only significantly affected in fruit stored at $70{ }^{\circ} \mathrm{F}$ during 2002 where fruit from trees on US-952 developed significantly more decay than all other rootstocks except US-942 (Table 2). Fruit stored at $38^{\circ} \mathrm{F}$ in 2001 developed significantly more decay than did fruit in 2002.

Percentage of 'Valencia' oranges with SERB after storage reached an overall mean of $24 \%$ over both years (Tables 1 and 2). Fruit from trees on Gou Tou $($ mean $=17 \%)$ and Swingle $($ mean $=16 \%)$ stored at either 70 or 38 ${ }^{\circ} \mathrm{F}$ were always in the group showing the lowest levels of SERB although fruit from trees on most other rootstocks did not develop significantly more SERB at $P=0.05$. Fruit from trees on US-952 were always in the group showing the highest levels of SERB ( mean $=34 \%$ ). Fruit from trees on Vangasay (mean = $20 \%)$ were in the group with lowest levels of SERB when stored at $70^{\circ} \mathrm{F}$ in 2001 , but displayed the highest level of

Table 2. Effects of rootstock on the percentage of 'Valencia' oranges developing stem-end rind breakdown (SERB) and decay after 35 or $98 \mathrm{~d}$ of storage at 70 or $38{ }^{\circ} \mathrm{F}\left(21.1\right.$ or $\left.3.3^{\circ} \mathrm{C}\right)$, respectively, with $90 \%$ relative humidity (2002).

\begin{tabular}{|c|c|c|c|c|}
\hline \multirow[b]{2}{*}{ Rootstock } & \multicolumn{2}{|c|}{$35 \mathrm{~d}$ at $70^{\circ} \mathrm{F}$} & \multicolumn{2}{|c|}{$98 \mathrm{~d}$ at $38^{\circ} \mathrm{F}$} \\
\hline & SERB (\%) & Decay (\%) & SERB (\%) & Decay (\%) \\
\hline Gou Tou & $0.0 \mathrm{~b}^{\mathrm{z}}$ & $11.7 \mathrm{~b}$ & $3.2 \mathrm{bc}$ & 5.9 \\
\hline Swingle citrumelo & $3.2 \mathrm{~b}$ & $11.9 \mathrm{~b}$ & $1.7 \mathrm{c}$ & 2.8 \\
\hline Vangasay lemon & $3.2 \mathrm{~b}$ & $11.1 \mathrm{~b}$ & $14.7 \mathrm{a}$ & 9.0 \\
\hline US-812 & $3.6 \mathrm{~b}$ & $8.2 \mathrm{~b}$ & $1.2 \mathrm{c}$ & 2.2 \\
\hline Sun Chu Sha mandarin & $1.3 \mathrm{~b}$ & $10.8 \mathrm{~b}$ & $7.8 \mathrm{abc}$ & 5.8 \\
\hline Carrizo citrange & $3.3 \mathrm{~b}$ & $5.8 \mathrm{~b}$ & $12.8 \mathrm{ab}$ & 9.9 \\
\hline US-942 & $7.3 \mathrm{ab}$ & $13.2 \mathrm{ab}$ & $12.3 \mathrm{ab}$ & 2.3 \\
\hline US-952 & $19.1 \mathrm{a}$ & $26.8 \mathrm{a}$ & $8.6 \mathrm{abc}$ & 2.4 \\
\hline Significance & ** & * & ** & NS \\
\hline
\end{tabular}

SERB when stored at $38^{\circ} \mathrm{F}$ in 2002 . Though there were significant differences in SERB development between rootstocks, differences in SERB on fruit from the more common commercial rootstocks (Carrizo, SCS, and Swingle) were usually nonsignificant.

Navel oranges. Rootstock significantly affected both SERB and postharvest decay in navel oranges (Table 3 ). SERB was relatively low $($ mean $=3 \%)$ in fruit grown on all rootstocks after $60 \mathrm{~d}$ storage at $50^{\circ} \mathrm{F}$. Similar to observations in 'Valencia', navel oranges from trees on Gou Tou developed the least SERB (0.5\%). However, it should be noted that Gou Tou has been eliminated from some rootstock trials in Florida because of poor growth and productivity (Wutscher and Bowman, 1999). Fruit from trees on Swingle and Carrizo displayed the greatest SERB, while fruit from trees on Cleopatra and SCS were intermediate. SERB on fruit from trees grown on the common commercial rootstocks (Carrizo, Cleopatra, SCS, and Swingle) were not significantly different from each other.

Moderately high levels of decay $($ mean $=15 \%)$ developed on navel oranges after $60 \mathrm{~d}$ of storage at $50{ }^{\circ} \mathrm{F}$ (Table 3). Fruit from trees on Cleopatra rootstock developed significantly less postharvest decay than the other rootstocks. Fruit from trees on Gou Tou developed significantly less decay than those from trees on Swingle or SCS. Fruit from Swingle developed significantly more decay than all rootstocks except SCS. These data contrast with McDonald and Wutscher (1974) who reported that 'Redblush' grapefruit growing on Cleopatra developed significantly more postharvest decay after 9 weeks storage at $50^{\circ} \mathrm{F}$ plus 1 week at $70^{\circ} \mathrm{F}$ than did fruit from Swingle $(20 \%$ vs. $9 \%$ respectively). They also observed 
no significant differences in decay of 'Redblush' grapefruit between Carrizo, SCS, or Cleopatra. Tree and fruit quality responses to different rootstocks may vary with citrus variety, growing region, etc. (Agusti, 1999; Castle and Gmitter, 1999) and likely contributed to differences between studies in different regions. In addition, $80 \%$ of the postharvest decay on grapefruit grown in Texas was caused by green mold (Penicillium digitatum), while in Florida, the majority ( $90 \%)$ of the decay came from stem-end rots (especially Diplodia natalensis). Rootstocks have been reported to affect tree growth and fruit peel characteristics that could in turn affect SERB and decay susceptibility (Agusti, 1999; Castle and Gmitter, 1999). For example, fruit with a thinner peel may loose water more readily leading to SERB, and tree growth characteristics that result in more canopy dead wood may lead to greater fruit infection from anthracnose (Colletotrichum gloeosporioides) and organisms causing stem-end rot such as Diplodia natalensis and Phomopsis citri (Brown and Miller, 1999).

'RAy Ruby' grapefruit. During storage at $70^{\circ} \mathrm{F}$, no SERB developed on 'Ray Ruby' grapefruit within the 37 d storage period. SERB did develop (mean $=8 \%)$ when fruit were stored for $98 \mathrm{~d}$ at $50{ }^{\circ} \mathrm{F}$, but differences between rootstock were not significant (Table 4).

Postharvest decay of 'Ray Ruby' grapefruit was significantly affected by rootstock (Table 4 ). As with navel oranges, fruit from trees on Cleopatra rootstock tended to result in the lowest postharvest decay. Decay on fruit from trees on Cleopatra was significantly lower than that of fruit from trees on sour orange or Carrizo after storage at $70^{\circ} \mathrm{F}$, and significantly lower than Carrizo after storage at $50^{\circ} \mathrm{F}$. Postharvest decay of fruit from trees on sour orange rootstock was variable with fruit stored at $70{ }^{\circ} \mathrm{F}$ developing relatively high levels of decay, and fruit stored at 50 ${ }^{\circ} \mathrm{F}$ developing relatively low levels of decay. While about $50 \%$ of citrus grown in the Indian River region is still grown on sour orange, very little is currently being planted because of its susceptibility to quick decline strains of citrus tristeza virus (Powell and Pelosi, 1993; Stover and Castle, 2002). McDonald and Wutscher (1974) reported that 'Redblush' grapefruit from two sour orange rootstocks tended to develop

Table 3. Effects of rootstock on the percentage of stemend rind breakdown (SERB) and decay of navel oranges after $60 \mathrm{~d}$ of storage at $50{ }^{\circ} \mathrm{F}\left(10.0{ }^{\circ} \mathrm{C}\right)$ with $90 \%$ relative humidity (2001-02).

\begin{tabular}{lcc}
\hline Rootstock & SERB (\%) & Decay (\%) \\
\hline Cleopatra mandarin & $2.3 \mathrm{ab}^{\mathrm{z}}$ & $7.5 \mathrm{~d}$ \\
Gou Tou & $0.5 \mathrm{~b}$ & $12.0 \mathrm{c}$ \\
Carrizo citrange & $4.5 \mathrm{a}$ & $15.3 \mathrm{bc}$ \\
Sun Chu Sha mandarin & $2.8 \mathrm{ab}$ & $18.5 \mathrm{ab}$ \\
Swingle citrumelo & $4.5 \mathrm{a}$ & $19.6 \mathrm{a}$ \\
Significance & $*$ & $* * *$ \\
"Values within each column followed by unlike letters are significantly different by \\
Duncan's multiple range test at $P \leq 0.05$. \\
${ }_{* * * * \text { Significant at } P \leq 0.05 \text { or } 0.001 .}$
\end{tabular}

Table 4. Effects of rootstock on the percentage of stem-end rind breakdown (SERB) and decay of 'Ray Ruby' grapefruit after 37 or $98 \mathrm{~d}$ of storage at 70 or $50{ }^{\circ} \mathrm{F}\left(21.1\right.$ or $\left.10.0^{\circ} \mathrm{C}\right)$, respectively, with $90 \%$ relative humidity (2002).

\begin{tabular}{lcccccc}
\hline & \multicolumn{2}{c}{ Storage at $\mathbf{7 0}{ }^{\circ} \mathbf{F}$} & & \multicolumn{2}{c}{ Storage at $\mathbf{5 0}{ }^{\circ} \mathbf{F}$} \\
\cline { 2 - 3 } \cline { 6 - 7 } Rootstock & SERB (\%) & Decay (\%) & & SERB (\%) & Decay (\%) \\
\hline Cleopatra mandarin & 0.0 & $17.8 \mathrm{~b}^{\mathrm{z}}$ & & 3.2 & $33.9 \mathrm{~b}$ \\
Sour orange & 0.0 & $30.6 \mathrm{a}$ & & 12.2 & $38.8 \mathrm{~b}$ \\
Swingle citrumelo & 0.0 & $22.5 \mathrm{ab}$ & & 8.8 & $44.9 \mathrm{ab}$ \\
Carrizo citrange & 0.0 & $28.5 \mathrm{a}$ & & 7.0 & $58.4 \mathrm{a}$ \\
Significance & $\mathrm{NS}$ & $*$ & & $\mathrm{NS}$ & $*$ \\
\hline
\end{tabular}

${ }^{2}$ Values within each column followed by unlike letters are significantly different by Duncan's multiple range test at $P \leq 0.05$.

ss, ${ }^{*}$ Nonsignificant or significant at $P \leq 0.05$.

Table 5. Effects of rootstock on the percentage of stemend rind breakdown (SERB) and decay of 'Oroblanco' fruit after $101 \mathrm{~d}$ of storage at $50^{\circ} \mathrm{F}\left(10 .{ }^{\circ} \mathrm{C}\right)$ with $90 \%$ relative humidity $(2002-03)$.

\begin{tabular}{lcc}
\hline Rootstock & SERB (\%) & Decay (\%) \\
\hline Sun Chu Sha mandarin & 9.2 & $8.0 \mathrm{c}^{\mathrm{z}}$ \\
Cleopatra mandarin & 3.4 & $11.6 \mathrm{bc}$ \\
$\times 639$ & 0.0 & $12.5 \mathrm{bc}$ \\
Swingle citrumelo & 6.8 & $16.3 \mathrm{bc}$ \\
Gou Tou & 6.1 & $18.8 \mathrm{abc}$ \\
Carrizo citrange & 1.1 & $20.9 \mathrm{abc}$ \\
Smooth Flat Seville & 4.5 & $22.9 \mathrm{abc}$ \\
Volkamer lemon & 6.7 & $31.0 \mathrm{ab}$ \\
Rough lemon 8166 & 1.2 & $39.9 \mathrm{a}$ \\
Significance & $\mathrm{NS}$ & $*$ \\
\hline
\end{tabular}

${ }^{2}$ Values within each column followed by unlike letters are significantly different by Duncan's multiple range test at $P \leq 0.05$.

Ns, "Nonsignificant or significant at $P \leq 0.05$

relatively low levels of postharvest decay from one rootstock selection, and moderate levels in the other, but that neither were significantly different from Cleopatra, SCS, Carrizo, or Swingle.

'Oroblanco'. SERB remained relatively low on 'Oroblanco' fruit after $101 \mathrm{~d}$ of storage at $50{ }^{\circ} \mathrm{F}$ (mean $=4 \%$; Table 5 ). SERB on 'Oroblanco' fruit was not significantly affected by rootstock in this experiment.

'Oroblanco' fruit developed moderate decay $($ mean $=20 \%)$ following $101 \mathrm{~d}$ storage at $50{ }^{\circ} \mathrm{F}$ (Table 5). Following storage, fruit from trees on SCS developed the least postharvest decay which was significantly lower than that from trees on SFS, Volkamer, and Rough lemon, but not significantly different from fruit grown on trees with the remaining rootstocks. Fruit from Cleopatra again tended to have relatively low levels of decay after storage, although they were not significantly different from the other commercial 
rootstocks (Carrizo, Cleopatra, SFS, SCS, or Swingle).

OVERALL TRENDS IN ROOTSTOCK INFLUENCE ON POSTHARVEST DISORDERs. Across all trials in which it was used, fruit from trees on Cleopatra consistently developed relatively low levels of decay and thus may be preferable for fresh fruit, especially when exported to distant markets. This contrasts markedly with the McDonald and Wutscher (1974) report that 'Redblush' grapefruit from SFS developed less postharvest decay than fruit from Carrizo, SCS, and Cleopatra. Thus, it is clear that the postharvest performance of fruit on a particular rootstock may change depending on growing location, scion variety, primary decay organisms, etc. In the current study, rough lemon and the similar Vangasay and Volkamer lemon rootstocks consistently conferred among the greatest levels postharvest decay, which again differs from results published by McDonald and Wutscher (1974) indicating that decay on fruit from rough lemon was among the lowest of the 21 rootstocks studied, including SCS and Cleopatra. Overall, SCS resulted in highly variable rates of decay, ranging from the least decay in 'Oroblanco' fruit, to almost the worst decay in navel oranges.

\section{Conclusions}

The current studies demonstrate that rootstock can affect postharvest SERB and decay susceptibility of fresh Florida citrus. When compared with previous reports, these data suggest that the relative performance of fruit from trees on different rootstocks may change depending on scion selection, growing location, etc. While juice quality evaluations are included in standard rootstock and scion breeding programs, quality evaluations during and after storage and transport through the marketing channels are seldom studied. Such attributes are critical for fruit produced primarily for the fresh market, especially given the growing importance of sales to distant markets. For example, in this study, SERB and postharvest decay could vary by $30 \%$ or more depending on rootstock. The authors suggest that evaluations of quality retention during storage be included when developing rootstocks and scion varieties for the fresh market.

\section{Literature cited}

Agusti, M. 1999. Preharvest factors affecting postharvest quality of citrus fruit, $\mathrm{p}$. 1-34. In: M. Schirra (ed.). Recent advances in the control of postharvest diseases and disorders of citrus fruit. Res. Signpost, Trivandrum, India.

Albrigo, L.G. 1972. Distribution of stomata and epicuticular wax on oranges as related to stem end rind breakdown and water loss. J. Amer. Soc. Hort. Sci. 97:220-223.

Brown, G.E. and W.R. Miller. 1999. Maintaining fruit health after harvest, p. 175-188. In: L.W. Timmer and L.W. Duncan (eds.). Citrus health management. APS Press, St. Paul, Minn.

Castle, W.S. 1987. Citrus rootstocks, p. 361-399. In: R.F. Carlson (ed.). Rootstocks for fruit crops. Wiley, New York.

Castle, W.S. and F.G. Gmitter. 1999. Rootstock and scion selection, p. 21-34. In: L.W. Timmer and L.W. Duncan (eds.). Citrus health management. APS Press, St. Paul, Minn.

D'hallewin, G., D. Mura, A. Piga, M. Pala, and G. Lovicu. 1994. Rootstock effects on postharvest physiological and pathological behaviour of 'Avana' mandarin. Acta Hort. 368:395-402.

Dou, H., J. Zhang, M.A. Ismail, and M. A. Ritenour. 2001. Postharvest factors influencing stem-end rind breakdown (SERB) of 'Valencia' oranges. Proc. Fla. State. Hort. Soc. 114:164-169.

Florida Department of State. 2003. Florida administrative code, chapter 20-Department of Citrus. Florida Dept. of State, Tallahassee. I Nov. 2003. <http://fac. dos.state.fl.us/>.

Grierson, W. 1965. Factors affecting postharvest market quality of citrus fruits. Proc. Amer. Soc. Hort. Sci., Caribbean Reg. 9:65-84.

Grierson, W. 1986. Physiological disorders, p. 361-378. In: W. F. Wardowski, S. Nagy and W. Grierson (eds.). Fresh citrus fruits. AVI, New York.

Hopkins, E.F. and A.A. McCornack. 1960. Effect of delayed handling and other factors on rind breakdown and decay in oranges. Proc. Fla. State Hort. Soc. 73:263-269.
McCollum, T.G., K.D. Bowman, and W.S. Castle. 2002. Effects of rootstock on fruit quality and postharvest behavior of 'Marsh' grapefruit. Proc. Fla. State Hort. Soc. 115:44-46.

McCornack, A.A. and W. Grierson. 1965. Practical measures for control of stem-end rind breakdown of oranges. Fla. Agr. Ext. Circ. 286.

McDonald, R.E. and H.K. Wutscher. 1974. Rootstocks affect postharvest decay of grapefruit. HortScience 9:455-456.

Patil, B.S. 2001. Location and rootstock affect sheepnosing in grapefruit. HortScience 36:710-713.

Powell, C.A. and R.R. Pelosi. 1993. Prevalence of severe strains of citrus tristeza virus in Florida citrus nurseries. HortScience 28:699-700.

Soost, R.K. and J.W. Cameron. 1980. 'Oroblanco', a triploid pummelo-grapefruit hybrid. HortScience 20:1134-1135.

Stearns, Jr., C.R. 1942. Report on fruit handling methods. Fla. Citrus Expt. Sta., Mimeo Rpt. 30 June.

Stover, E. and W. Castle. 2002. Citrus rootstock usage, characteristics, and selection in the Florida Indian River region. HortTechnology 12:143-147.

Stover, E., R. Pelosi, M. Burton, S. Ciliento, and M. Ritenour. 2004. Performance of 'Oroblanco' and 'Melogold' pummelo $x$ grapefruit hybrids on nine rootstocks on a calcareous, poorly drained soil. HortScience 39:28-32.

Treeby, M.T., R. Storey, and K.B. Bevington. 1995. Rootstock, seasonal, and fruit size influences on the incidence and severity of albedo breakdown in Bellamy navel oranges. Austral. J. Experimental Agr. 35:103-108.

Wutscher, H.K. and K.D. Bowman. 1999. Performance of 'Valencia' orange on 21 rootstocks in central Florida. HortScience 34:622-624.

Zekri, M. 2000. Citrus rootstocks affect scion nutrition, fruit quality, growth, yield, and economical return. Fruits 55:231-239. 